\title{
Legacy of the ad hoc International Criminal Tribunals in Implementing International Humanitarian Law
}

\author{
Agnieszka Szpak, LLD \\ Nicolas Copernicus University in Torun, Poland \\ Faculty of Political Sciences and International Studies \\ Department of International and European Law \\ e-mail: aszpak@umk.pl
}

\section{Doi:10.5901/mjss.2013.v4n9p525}

\section{Abstract}

The aim of the Article is to show that both the ICTY and the ICTR played a very important role in the implementation of international humanitarian law and that they themselves should be regarded as a special mechanism of implementation. International criminal tribunals contributed to clarifying a significant number of international humanitarian law norms making this branch of international law more clear and coherent. The unity and coherence of the jurisprudence of the International Criminal Tribunals for the former Yugoslavia and Rwanda provides stability, certainty and predictability of humanitarian law and those values are important for every legal system.

The International Criminal Tribunal for the former Yugoslavia (hereinafter: ICTY) was convened by the Security Council resolution no. 827 (1993) whereas the International Criminal Tribunal for Rwanda (hereinafter: ICTR) by resolution no. 955 (1994) (UN SC res. 827 (1993), UN SC res. 955 (1994), Meernik 2003, Joyner 1995-96, Tung 2000). In accordance with the ICTY Statute of 25 May 1993, the Tribunal shall have the power to prosecute persons responsible for serious violations of international humanitarian law committed in the territory of the former Yugoslavia since 1991. Articles 2-5 enumerate offences falling under the Tribunal's jurisdiction, namely grave breaches of the Geneva Conventions of 1949, violations of the laws or customs of war, genocide and crimes against humanity (Statute of the ICTY).

The ICTR Statute of 8 November 1994 states that the Tribunal "shall have the power to prosecute persons responsible for serious violations of international humanitarian law committed in the territory of Rwanda and Rwandan citizens responsible for such violations committed in the territory of neighbouring States between 1 January 1994 and 31 December 1994". The crimes falling under ICTR's jurisdiction include genocide, crimes against humanity and violations of Article 3 Common to the Geneva Conventions and of Additional Protocol II (the last category being war crimes committed in the non-international armed conflicts) (Statute of the ICTR).

Both the ICTY and the ICTR are surely one of the most important institutions in the history of international law, not only for its catalytic effect in generating trials for international crimes before both international and domestic courts but also for breathing new life into both international humanitarian and criminal law (Steward 2013).

This article attempts to prove that both the ICTY and the ICTR played a very important role in the implementation of international humanitarian law (hereinafter: $\mathrm{IHL}$ ) and that they themselves should be regarded as a special mechanism of implementation which is utilized when the rules of IHL were breached. The article requires from the reader some knowledge of the jurisprudence of the ad hoc international criminal tribunals as for the lack of more space it was impossible to refer to the detailed judgments of the Tribunals. I refer to them but without explaining in details the Tribunals' legal arguments and analysis.

Before ICTY and ICTR, judgments interpreting and implementing international humanitarian law have not been rendered. Except for the Nuremberg and Tokyo judgments when the ad hoc international criminal tribunals were convened the latter had no precedents or interpretative guidelines to use (Wang 1995-1996). International criminal tribunals contributed to clarifying a significant number of $\mathrm{IHL}$ norms making this branch of international law more clear and coherent. Among others the following notions were clarified: 'civilian population', 'widespread or systematic attack', or 'nexus between crimes and an armed conflict'. The particular crimes falling under the jurisdiction of the ICTY/ICTR were also defined. Although the ICTY and the ICTR "[...] have flown the flag of customary law, many new doctrines have grown up and many new fact situations have been accommodated under old labels and rubrics" (Wald 2007). Among the new concepts one can place for example the 'overall control' test from the ICTY Appeals Chamber judgment in the Tadic case (1999) or the progressive definition of the persons protected by the Geneva Convention IV relative to the protection 
of civilian population (hereinafter: GC IV), this definition putting the main emphasis rather on the ethnic affiliation than formal bonds of nationality. The last concept was formulated in the ICTY Trial Chamber judgment in the Celebici case (1998).

When one thinks of the ad hoc international criminal tribunals as a mechanism of implementing $\mathrm{HL}$, the clarification of the notions and terms of art of $\mathrm{IHL}$ is of a crucial importance because IHL treaties such as the four Geneva Conventions on the protection of victims of war of 1949 and their Additional Protocols of 1977 while prohibiting certain acts do not necessarily define them. As I. Šimonović claims, "[i]nternational law, mostly a product of multilateral negotiations, is frequently articulated in a highly abstract manner, often ambiguously and obscurely" (Šimonović 19992000). Very often the provision does not define the terms used in it. A good example of this is the notion of 'genocide' which was adopted in Art. 1 of the 1948 Convention on the Prevention and Punishment of the Crime of Genocide. The authors of the definition of genocide did not clarify what national, ethnical, racial or religious group means or what the intent to destroy the group as such entails.

Generally, although it is relatively easy prima facie to identify which types of acts constitute war crimes, it is often quite difficult to spell out the elements of individual offenses because substantial portions of $\mathrm{IHL}$ are expressed at a high level of abstraction or generality (despite its high specificity) and because many offenses have rarely, if ever, been prosecuted in criminal courts (Fenrick 1998-1999). Specificity, in other words quite strong formalism of IHL, is evidenced by - for instance - Geneva Convention III relative to treatment of prisoners of war (hereinafter: GC III) which contains mostly self-executing norms. This means that they may be applied without implementing them into national legal order (as they are clear, precise, unconditional and complete). As J. Sandorski noticed, what is decisive of self-executing character of a norm is inter alia the intent of the States-parties. This intent was present in the minds of the authors of IHL treaties because they were aware of the fact that during an armed conflict self-executing norms are most useful (Sandorski 2004). Only certain provisions need to be implemented, for example Arts. 129 and 130 of GC III (adopting penal provisions necessary to prosecute and punish the perpetrators of the breaches of the Convention).

The progressive, even pioneering role of the ICTY and the ICTR lies precisely in them defining the particular crimes falling under their jurisdiction. Their failure could undermine the credibility of the whole IHL because an attempt to bring violators of IHL to justice would fail. The fiasco of the implementation mechanism, namely of the ICTY/ICTR could negatively affect the implemented material, i.e. IHL. The success of the Tribunals will strengthen the deterrent effect while their failure may bury this very desired effect (Greenwood 1993, Andrews 1997). As T. Meron states, "[t]he credibility of the international system of justice requires prosecutions for atrocities everywhere" (Andrews 1997, Stroud 1997) and as such it requires the establishment of the ICTY and the ICTR.

There are however opinions voiced that the Tribunals could be deemed a success even if they ultimately attained only symbolic achievements without any actual infliction of punishment (Andrews 1997). Accordingly, the establishment of the Tribunals is a success in itself. I am convinced that the jurisprudence of the ad hoc international criminal tribunals should be highly regarded. As has already been mentioned, mostly because their jurisprudence contributed immensely to the development of $\mathrm{IHL}$. As the Polish prosecutor J. Sawicki said in his opening speech in the Majdanek concentration camp trial, court judgments are small bricks which serve to build an edifice. Maybe in the beginning the edifice is fragile, vulnerable to disruptions and whirlwinds of the law which will gather power and executive ability after this war, namely the Second World War (M. Królikowski, P. Wiliński, J. Izydorczyk, M. Znojek 2010). This statement is entirely true and up to date today in the context of new wars that broke out after the Second World War as well as with regard to the ad hoc international criminal tribunals. Their jurisprudence is of even more value and meaning as it exhibits a very high level of unity and coherence. This unity and coherence provides stability, certainty and predictability of IHL and those values are important for every legal system.

With regard to the deterrent role and effect of the workings of the ICTY and the ICTR, the scholars indicate that genocide in Srebrenica (in 1995) was committed after the establishment of the ICTY and its initial work and consequently the Tribunal was not effective and did not fulfill its deterrent role. Similar charges were levied against the ICTR with regard to genocide and the ICTR's influence (or rather lack thereof, i.e. lack of deterrent effect) on the perpetrators of massacres in Darfur (Sudan). Still - as F. Baroni rightly indicates - "[...] we must not forget that the court's contribution to peace is a long-term process that cannot be measured and valued in the short run" (Baroni 2000, McDonald 2004). The accusations referring to the deterrent role of the ICTY/ICTR are not exactly right as one can pose a question - who would seriously criticize criminal courts at the national level simply because crimes are still committed? Criminal law deals with situations where all other political, economic and social structures have failed. It is unrealistic to put these high expectations to succeed on the Court where the rest of society has failed (Baroni 2000). It is sufficient that to a certain extent the ICTY and the ICTR do contribute to crime prevention. It is difficult to specify it in the percentage number but it 
seems to me quite obvious that a hundred percent efficiency of any criminal tribunal or court in deterrence is impossible. A. M. Danner states, "[d]espite these cautionary voices, it is difficult to imagine that the recent enforcement of international criminal law will exert no deterrent effect. The absence of institutions like the Tribunals and the International Criminal Court (hereinafter: ICC) arguably encourages the commission of atrocities [...] Empirical studies have suggested that the presence of a criminal justice system acts as a deterrent. Before the establishment of the Tribunals, there existed no functioning international criminal justice system. At least for those in the former Yugoslavia and Rwanda, this absence of accountability has changed significantly" (Danner 2001, Akhavan 1998).

It should also be emphasized that the role of ad hoc international criminal tribunals consists first of all of bringing the perpetrators of crimes to justice. Perpetrators of crimes already committed. The characteristic feature of the criminal trial is its reactivity which means that the proceedings take place after the crime was committed. This conclusion seems a cliché but it is not always remembered that the main role of the ICTY and the ICTR as well is to punish criminals and only secondarily to deter future or potential criminals. The work of the Tribunals will not root out the evil of this world. However, as P. Akhavan claims with reference to the ICTY, "[i]t should be underscored that beyond its impact on the former Yugoslavia, the ICTY is also an essential contribution to eradicating the culture of impunity that has characterized international relations for so long. If effective, the ICTY will contribute to general deterrence in the world community through the moral propaganda of international criminal justice" (Akhavan 1998).

It is significant to stress that with the establishment of the ad hoc international criminal tribunals, as well as hybrid or mixed tribunals (Mendez 2009) and the permanent International Criminal Court, gross violations of humanitarian law are, for the first time, systematically prosecuted, thereby - as F. Baroni claims "[...] upgrading humanitarian laws from empty words to enforceable behavioral standards" (Baroni 2000, Jorda 2004, Moghalu 2005). The scale of the prosecutions is absolutely unique - taking into account the quality, quantity and timeframe of those proceedings.

The ICTY and the ICTR try perpetrators of international crimes including high State officials, for example heads of State or government. Their work - despite its temporariness expressing their ad hoc nature - embraces about 20 years. From the IHL standpoint jurisprudence of ad hoc international criminal tribunals is relevant also because it determined what law was applicable in a given situation, because the perpetrators of that law were punished and new standards were established (Moghalu 2005). It should be stated in this context that the ICTY and the ICTR have substantially expanded the interpretation of $\mathrm{IHL}$ relating to sexual violence. The Tribunals have made enormous strides just by acknowledging the role of sexual violence in ethnic cleansing and genocide, and by convicting defendants of individual acts of rape and assault (Dubin 2003) (for instance in the Akayesu case before the ICTR and in the cases of Celebici as well as Kunarać, Kovać and Vuković before the ICTY). As S. K. Dubin rightly noticed, "[t]he legal recognition of the relationship between sexual violence and ethnic cleansing in Yugoslavia, and between sexual violence and genocide in Rwanda, has been an enormous step forward for international justice" (Dubin 2003).

One cannot however forget about other critical voices, according to which the rudimentary task of the criminal court is to try the case and not write the textbook on every possible legal issue that comes up during the proceedings. Some scholars are of the opinion that especially the ICTY does this (Murphy 1999). In my opinion such critical voices are not right as such extensive activities of the ad hoc international criminal tribunals expressing judicial activism cause many notions and issues to be defined and clarified and this in turn enormously influences the implementation of $\mathrm{HLL}$, especially in the case of legal lacunae. Furthermore, the Tribunals had no precedents nor legal guidelines to use as for the last sixty years that have passed since the Nuremberg and Tokyo judgments were issued, no other international tribunals operated (Moghalu 2005). Such extensive and progressive activities of the ICTY and the ICTR as well as dynamic interpretation of legal norms marks development of international legal system. W. Czapliński claims that the conclusion reached by some authors that international courts concentrate on trying the case and do not exceed the framework defined by the parties, is not so obvious. The principle of judicial restraint is a desirable postulate but at the same time it is difficult not to be under the impression that international courts attempt - through its jurisprudence - to influence the directions of development of international law (Czapliński 2007). This correct remark fully pertains to the ICTY and the ICTR.

With regard to the ICTY some authors also accused it of not prosecuting the principal war criminals. Recently mainly R. Mladić was at large; he was apprehended in May 2011. But despite the death of S. Milosević, the fact that the international community even indicted Milosevic is a significant step (Miller 1999-2000, Scharf 2001-2002). It might have been presumed that if Milosović had not died he would have been convicted after a fair trial. It should as well be noticed that the trial of R. Karadzić is still going on. Karadzić is charged with genocide, crimes against humanity (persecution, extermination, murders, other inhumane acts) and violations of the laws and customs of war (killings, terrorizing civilian population, unlawful attacks on civilian population, taking hostages). His trial began on 26 October 2009 (Radovan 
Karadzić. Case Information Sheet). The same charge cannot however be levied against the ICTR as it tried high State officials such as prime minister Jean Kambanda, minister for foreign affairs Jean Bosco Barayagwiza, minister for culture and education Jean de Dieu Kamuhanda orminister for finance Emmanuel Ndindabahizi.

As S. D. Murphy stressed, the ICTY (which pertains to the ICTR) "[...] is far from perfect; it carries a bureaucracy endemic to most large institutions. Yet many of the problems faced by the ICTY are a product of the difficult conditions in which it operates, as it must rely almost exclusively on cooperation by states to obtain information, financial support and custody of indictees. The real success of the ICTY lies in the fact that, despite these obstacles, it is a functioning international criminal court that is providing a forum for victims to accuse those who violated civilized norms of behavior; creating and preserving a historical record of the events in the former Yugoslavia; [...] and generating a body of jurisprudence that will undoubtedly continue to build over time and strongly influence the development of international humanitarian law, as well as international law generally" (Murphy 1999). Moreover, it is difficult to somehow estimate and deem too expensive the task of bringing perpetrators of international crimes to justice, perpetrators responsible for death of hundreds of thousands if not millions of people. We should remember about the victims who expect that justice will be done. Can a price for this ever be too high? Or can it be estimated in money?

Like E. la Haye does, one may ask - is the ICTY/R's jurisprudence a constructive, in other words creative, interpretation of $\mathrm{IHL}$ or rather exact depiction of the present state of customary international law? G. Aldrich gives partial answer to this question. In his opinion, including within the crimes falling under the ICC jurisdiction war crimes committed in noninternational (Art. 8, paragraph 2 (c) and (e) of the ICC Statute) shows that the creative work of the Yugoslav Tribunal has been welcomed (Aldrich 2000). This is an example of the influence of the ICTY's jurisprudence over the rules adopted in the ICC Statute. Consequently, it might be claimed that States-parties of the ICC Statute approved and affirmed the interpretation of IHL given by the ad hoc international criminal tribunals. Another conclusion that should be drawn is that the Tribunals created a momentum which led to a breakthrough of certain barriers (such a lack of political will or the barrier of sovereignty). This is evidenced by the establishment of the ICC. There is also another lesson, maybe trivial but in my opinion worth emphasizing, namely, that international justice requires patience (Wierda 2002-2003). The functioning of the ICTY and the ICTR has demonstrated beyond any question the need for a permanent International Criminal Court which should continue the work of its predecessors (Washburn 2002-2003).

One may question or contest the degree of significance of the judgments of the ICTY and the ICTR but not the fact that they do have some significance. Jurisprudence of both of the Tribunals contributed to 'interaction, interpretation, and internalization' (Bingham 2006) of IHL. The so called public opinion heard about IHL, knowledge thereof materialized in the mind of an average men/citizen and in the minds of experts other than lawyers. At the same time the judicial workings of the Tribunals aroused the interest of the public opinion and academics in IHL and in this way partly created atmosphere favourable to the establishment of the ICC. Before the establishment of the ICTY and the ICTR and their first judgments, the interest in IHL was rather moderate. It was exactly indeed the establishment of the ad hoc criminal tribunals and then the ICC that awakened this interest again. It is definitely important as the views of the scholars may also contribute to the development of IHL by inspiring and influencing the behavior of States and individuals and through that leading to the adoption of concrete legal norms.

Jurisprudence of international courts, including the ad hoc international criminal tribunals, is very extensive and diverse and as such it absolutely contributes to the development of international law, IHL inclusive. Such development brings with it - next to the opportunities - also some dangers and challenges such as fragmentation of international law which may jeopardize the unity of international law and "[...] give rise to a serious risk of conflicting jurisprudence as the same rule of law might be given different interpretations in different cases" (Lindroos 2005). International courts issue judicial decisions that may be contradictory or may give precedence to norms of one legal system over the other. The most widely given example is the Tadić 'overall control' test contrasted with the ICJ 'effective control' test from the Nicaragua case. However, taking into account the fact that facts of those two cases were very much different, the risk of fragmentation or lack of unity of international law is rather illusory than real.

I. Bantekas claims that "[...]international tribunals are making a significant effort to pass through the back door a variety of principles that serve their purposes by elevating them to the status of general principles of international criminal/humanitarian law, but which are of dubious legal standing" (Bantekas 2006). The ICTY and the ICTR frequently confirmed the binding character of customary law norm without a thorough analysis of the State practice and sometimes even - as has been criticized - when the expressions of practice were very rare. As T. Meron pointed out, the binding law somehow turned into the law that should be binding (we can say - an ideal law); "the 'ought' merges with the 'is,' the lex ferenda with the lex lata". The teleological need to reinforce the contents of IHL clearly influenced the attitude of the judges and adoption - on the basis of the gravity of the crimes alleged - such an expansive and progressive stand. The 
more cruel the crime the more probable it is that the ICTY or the ICTR will conclude that it violates not only the principles of humanity or of the public conscience but also customary international law norms (Dingwall 2004).

This trend is reflected especially in the jurisprudence of the ICTY. For example, it is evident in the Kupreskic Trial Judgment (2000), which also reveals the role that the Martens Clause, and thus the principle of humanity, may play in formation of customary IHL. In the Kupreskic case Trial Chamber held that: "[i]n the light of the way States and courts have implemented it, [the Martens] Clause clearly shows that principles of international humanitarian law may emerge through a customary process under the pressure of the demands of humanity or the dictates of public conscience, even where State practice is scant or inconsistent" (Prosecutor v. M. Kupreskić, Trial Chamber 2000). In other words, the ICTY recognized that the Martens clause and the demands of humanity or the dictates of public conscience, listed therein, may play a significant role in the emergence of customary $\mathrm{IHL}$ and this being so despite sporadic and inconsequential State practice or even the lack of it. To put it differently, strong and clear opinio iuris would be decisive for the establishment of customary international legal norm. Such a strong reliance on opinio iuris may be found reasonable and justified (in particular with regard to IHL fundamental norms) as in the case of $\mathrm{IHL}$ applicable to armed conflicts the lack of the possibility of expressing acceptance of a certain rule by way of practice cannot be equated with the lack of this practice as a necessary element of customary law norm. As S. Haynes accurately asks "[h]ave we really got to wait until most of states have been able to demonstrate their physical support for rules during actual combat before we declare a rule to have achieved customary law status? One hopes not, especially as this would lead, through consistency, to an unfortunate situation in which no rule contained in the law of armed conflict could ever be accepted as customary law until the vast majority of states had actually deployed their armed forces in combat and demonstrably applied the rule for all to see. Since none of us have any general desire to see states actively engaged in armed conflict, this would mean that we would all hope never to see rules of customary law developed at all in this vital area if international law. This would clearly be unfortunate" (Haines 2007). Emergence of custom in IHL is tightly connected with normative statements of the academics and judges rather than with the long-term State practice during an armed conflict. It is quite understandable as the State practice contrary to the demands of humanity or the dictates of public conscience was and still is a motivating factor in the development of new standards in $\mathrm{IHL}$ and institutional forms of their implementation.

On the other hand, E. Wilmshurst and S. Breau cautioned that "[c]odified international law is the subject of agreement among States after lengthy negotiations. It is inevitably subject to compromise and practical reality, which may water down the desirable to the feasible. If States find that customary law is being used to 'raise the bar' so that requirements are being imposed which States would not be prepared to accept at the conference table on grounds of practicality, then the whole structure of customary law, as providing foundation for treaty law and underpinning the legal system, may be cast in doubt" (Wilmshurst, Breau 2009, Emanueli 2009).

I should also stress here the role of the ICTY in eradicating the dichotomy between the law applicable to international armed conflicts and the one applicable to non-international armed conflicts. Having confirmed that many of the offences that were crimes in international armed conflict were of customary nature, and as such also crimes in noninternational armed conflict, the Tribunal to a great extent solved the problem of determining in each case the nature of an armed conflict as the applicable customary international humanitarian law (fundamental rules) is the same for both types of an armed conflict (Wilmshurst, Breau 2009). It is worth quoting here a fundamental statement of the Appeals Chamber in the Celebici case: "In light of the fact that the majority of the conflicts in the contemporary world are internal, to maintain a distinction between the two legal regimes [of armed conflicts - international and non-international - A. Sz.] and their criminal consequences in respect of similarly egregious acts because of the difference in nature of the conflicts would ignore the very purpose of the Geneva Conventions, which is to protect the dignity of the human person" (Prosecutor v. Z. Delalić, Z. Mucić, H. Delić, E. Landzo, Appeals Chamber 2001). In other words, in light of the evolution of armed conflicts and an increasing number of internal armed conflicts it is more and more difficult to justify this distinction (Emanueli 2009). Unfortunately, in the current state of international law the two box approach: one box with norms on international armed conflicts and the other with norms on non-international armed conflicts is still present. ICTY contributed immensely to getting away with this disparity which was to a large extent removed in the ICC Statute.

In the end it is worth quoting judge G. K. McDonald: "[t]he judgments of the Tribunals do more than determine the guilt or innocence of the accused. They do more than establish a historical record of what transpired. They do more than interpret international humanitarian law. Rather, the judgments of the Tribunals are evidence of actual enforcement of international norms. This is the best proof that the numerous conventions, protocols, and resolutions affirming human dignity are more than promises. Rather, the rule of law is an important component of the peace process" (McDonald 2000-2001, Nsereko 2008, Schrag 1997).

The jurisprudence of the ICTY and the ICTR is a mechanism of IHL implementation. The prosecution and 
punishment of the perpetrators of international crimes may have deterrent effect - apart from the obvious repressive effect. Prosecution in some way brings into reality the implementation of IHL. As a result the crimes are detected, given names and perpetrators brought to justice. Such a result of the judicial functions of the ICTY and the ICTR is especially important. Despite being frequently violated, the IHL rules are not a dead letter and due to both the ICTY and the ICTR, they have been re-validated, reinvigorated, rendered more credible and strengthened.

\section{References}

Akhavan P. (1998). Justice in The Hague, Peace in the Former Yugoslavia? A Commentary on the United Nations War Crimes Tribunal. Human Rights Quarterly, 20, 746-751.

Aldrich G. H. (2000). The Laws of War on Land. American Journal of International Law, 94, 42-63.

Andrews L. W. (1997). Sailing Around The Flat Earth: The International Tribunal For The Former Yugoslavia As A Failure Of Jurisprudential Theory. Emory International Law Review, 11, 471-514.

Bantekas I. (2006). Reflections on Some Sources and Methods of International Criminal and Humanitarian Law. International Criminal Law Review, 6, 121-136.

Baroni F. (2000). The International Criminal Tribunal for the Former Yugoslavia and Its Mission to Restore Peace. Pace International Law Review, 12, 233-252.

Bingham L. (2006). Strategy or Process? Closing the International Criminal Tribunals for the Former Yugoslavia and Rwanda. Berkeley Journal of International Law, 24, 687-717.

Czapliński W. (2007). Multiplikacja sądów międzynarodowych - szansa czy zagrożenie dla jedności prawa międzynarodowego. In J. Kolasa and A. Kozłowski (Eds.), Rozwój prawa międzynarodowego - jedność czy fragmentacja? Konferencja Katedr Prawa Międzynarodowego, Karpacz, 10-12 maja 2006 (pp.77-130). Wrocław: Wydawnictwo Uniwersytetu Wrocławskiego.

Danner A. M. (2001). Constructing A Hierarchy of Crimes in International Criminal Law. Virginia Law Review, 3, 415-501.

Dingwall J. (2004). Unlawful Confinement As a War Crime: The Jurisprudence of the Yugoslav Tribunal and the Common Core of International Humanitarian Law applicable to Contemporary Armed Conflicts. Journal of Conflict \& Security Law, 2, 133-179.

Dubin S. K. (2003). Memorandum for the Office of the Prosecutor of the I.C.T.R. A Comparative Study of Sexual Violence. Trials in the ICTY and ICTR Comparing Six Particular Issues. [Online] Available: http://law.case.edu/War-CrimesResearchPortal/memoranda/SexualViolence.pdf (October 13, 2010).

Emanuelli C. (2009). International Humanitarian Law (2009). Québec: Éditions Yvon Blais.

Fenrick W. J. (1998-99). Should Crimes Against Humanity Replace War Crimes?. Columbia Journal of Transnational Law 37, 767-786.

Greenwood Ch. (1997). The International Tribunal for former Yugoslavia, International Affairs 4, 641-655.

Haines S. (2007). The United Kingdom and Legitimate Military Objectives: Current Practice ... and Future Trends?'. In W. Heintschel von Heinegg and V. Epping (Eds.), International Humanitarian Law Facing New Challenges. Symposium in Honour of Knut Ipsen (pp. 127-141). Berlin: Springer.

Jorda C. (2004). The Major Hurdles and Accomplishments of the ICTY. What the ICC Can Learn from Them. Journal of International Criminal Justice, 2, 572-584.

Joyner Ch. C (1995-96). Strengthening enforcement of humanitarian law: Reflections on the International Criminal Tribunal for the Former Yugoslavia. Duke Journal of Comparative \& International Law, 5, 79-102.

Królikowski M., Wiliński P., Izydorczyk J., Znojek M. (Eds.) (2010). Prawo karne międzynarodowe. Wybór źródeł. Kraków: Kantor Wydawniczy "Zakamycze".

Lindroos A. (2005). Addressing Norm Conflicts in a Fragmented Legal System: The Doctrine of Lex Specialis. Nordic Journal of International Law, 74, 27-66.

McDonald G. K. (2000-2001). The International Criminal Tribunals: Crime and Punishment in the International Arena. Nova Law Reiew, $25,463-484$.

McDonald G. K. (2004). Problems, Obstacles and Achievements of the ICTY. Journal of International Criminal Justice, 2, 558-571.

Meernik J. (2003). Victor's Justice or the Law?. Journal of Conflict Resolution, 47, 140-162.

Mendez P. K. (2009). The New Wave of Hybrid Tribunals: a Sophisticated Approach to Enforcing International Humanitarian Law or an Idealistic Solution with Empty Promises?. Criminal Law Forum, 4, 53-95.

Miller W. (1999-2000). Slobodan Milosevic's Prosecution by the International Criminal Tribunal for the Former Yugoslavia: A Harbinger of Things to Come for International Criminal Justice. Loyola Los Angeles International \& Comparative Law Review, 22, 553-580.

Moghalu K. Ch. (2005). Rwanda's Genocide. The Politics of Global Justice. New York: Palgrave MacMillan.

Murphy S. D. (1999). Progress and Jurisprudence of the International Criminal Tribunal for the Former Yugoslavia. American Journal of International Law, 93, 57-97.

Nsereko D. D. N. (2008). The Role of the International Criminal Tribunals in the Promotion of Peace and Justice: The Case of the International Criminal Court. Criminal Law Forum, 19, 373-393.

Prosecutor v. M. Kupreskić, Trial Chamber 2000. [Online] Available: http://www.icty.org/action/cases/4 (April 26, 2013).

Prosecutor v. Z. Delalić, Z. Mucić, H. Delić, E. Landzo, Appeals Chamber 2001. [Online] Available: http://www.icty.org/action/cases/4 (April 26, 2013).

Radovan Karadzić. Case Information Sheet. [Online] Available: http://www.icty.org/x/cases/karadzic/cis/en/cis_karadzic_en.pdf (October 
13, 2010).

Sandorski J. (2004). Opieka konsularna a opieka nad jeńcami wojennymi w świetle sprawy kombatantów afgańskich. In J. Białocerkiewicz, M. Balcerzak and A. Czeczko-Durlak (Eds.), Księga Jubileuszowa Profesora Tadeusza Jasudowicza (pp. 363398). Toruń: TNOiK;

Schrag M. (1997). The Yugoslav War Crimes Tribunal: An Interim Assessment. Transnational Law \& Contemporary Problems, 7, 15-20.

Šimonović I. (1999-2000). The Role of the ICTY in the Development of International Criminal Adjudication. Fordham International Law Journal, 23, 440-459.

Sluiter G. (2008). Karadzić on Trial: Two Procedural Problems. [Online] Available: http://www.haguejusticeportal.net/smartsite.html?id=2 (October 13, 2010).

Statute of the ICTY. [Online] Available: http://www.icty.org/x/file/Legal\%20Library/Statute/statute_sept08_en.pdf (April 26, 2013).

Statute of the ICTR. [Online] Available: http://69.94.11.53/ENGLISH/basicdocs/statute/2007.pdf (April 26, 2013).

Steward J. G., Guest Post: The ICTY Loses its Way on Complicity - Part 1. [Online] Available: http://opiniojuris.org/2013/04/03/guestpost-the-icty-loses-its-way-on-complicity-part-1/ (April 26, 2013).

Stroud J. (1997). International criminal jurisdiction, international humanitarian law and humanitarian action. International Review of the Red Cross, 321, 623-634.Scharf M. (2001-2002). The International Trial of Slobodan Milosevic: Real Justice or Realpolitik? ILSA Journal of International \& Comparative Law, 8, 389-402.

Tung Ch. Y. (2000). The implementation of international humanitarian law by the United Nations. Case study in the former Yugoslavia. In E. Frangou-Ikonomidou, C. Philotheou, D. Tsotsoli (Eds.), Peace and Human Rights (pp. 413-420). Thessaloniki: Institute of International Public Law and International Relations.

UN SC Resolution 827 (1993). [Online] Available : http://www.un.org/en/sc/documents/resolutions/ (April 26, 2013).

UN SC Resolution 955 (1994). [Online] Available : http://www.un.org/en/sc/documents/resolutions/ (April 26, 2013).

Wald P. M. (2007). Tribunal Discourse and Intercourse: How the International Courts Speak to One Another. Boston College International \& Comparative Law Review, 30, 15-28.

Wang M. M. (1995-96). The International Tribunal for Rwanda: Opportunities for Clarification, Opportunities for Impact. Columbia Human Rights Law Review, 27, 177-226.

Washburn J. L. (2002-2003). Milosevic, Killing Fields, And „Kangaroo” Courts: Symposium on an Emerging International Criminal Justice System. What Lessons Can Be Learned From the Ad Hoc Criminal Tribunals? University of California Davis Journal of International Law \& Policy, 9, 23-30.

Wierda M. L. (2002-2003). Milosevic, Killing Fields, And „Kangaroo” Courts: Symposium on an Emerging International Criminal Justice System. What Lessons Can Be Learned From the Ad Hoc Criminal Tribunals? University of California Davis Journal of International Law \& Policy, 9, 13-22.

Wilmshurst E., Breau S. (2007). Perspectives on the ICRC Study on Customary Humanitarian Law. Cambridge: Cambridge University Press. 